\title{
Pencarian informasi melalui televisi dan film oleh tunarungu di Sumedang
}

\author{
Azmah Tafwidli Rahmi ${ }^{1}$, Santi Susanti ${ }^{2}$, Herlina Agustin ${ }^{3}$ \\ 1,2,3 Universitas Padjadjaran, Bandung, Indonesia
}

\begin{abstract}
ABSTRAK
Setiap warga negara berhak mendapatkan informasi dan akses informasi termasuk disabilitas tunarungu, sebagaimana dijamin pasal 18 F UUD 1945, yang menyatakan bahwa setiap orang berhak berkomunikasi dan memperoleh informasi. Informasi dapat diperoleh dari beragam sumber, termasuk televisi dan film. Bagi disabilitas tunarungu, keterbatasan yang mereka miliki berpengaruh terhadap akses informasi di televisi dan film. Penelitian ini bertujuan mengungkapkan motif yang mendorong anggota Gerakan untuk Kesejahteraan Tunarungu Indonesia (Gerkatin) Kabupaten Sumedang membutuhkan informasi dari televisi dan film, serta upaya yang dilakukan untuk memenuhi kebutuhan informasi tersebut. Metode yang digunakan adalah kualitatif dengan pendekatan studi kasus. Pengumpulan data dilakukan melalui wawancara, observasi serta dokumen yang relevan dengan penelitian. Analisis data dilakukan menggunakan metode analisis data interaktif Miles dan Huberman. Hasil penelitian menunjukkan bahwa pemenuhan kebutuhan informasi melalui televisi dan film pada disabilitas tunarungu di Gerkatin Sumedang digerakkan oleh motivasi internal dan eksternal berdasarkan sepuluh faktor kebutuhan berbeda pada setiap individu, antara lain kebutuhan akan hiburan, informasi dan pekerjaan. Film komedi dan aksi lebih mudah dipahami informasinya, karena penyampaiannya lebih menarik dan tidak berbelit. Pemenuhan kebutuhan informasi melalui film dilakukan dengan menonton di bioskop dan Youtube. Informasi di televisi dan film masih sulit diakses, karena kurangnya ketersediaan juru Bahasa isyarat serta teks di dalam setiap tayangan televisi dan film di bioskop. Oleh karena itu, teman tuli di Gerkatin Kabupaten Sumedang berharap adanya teks film dan Juru Bahasa Isyarat dalam setiap tayangan film, agar film Indonesia menjadi ramah bagi disabilitas turarungu.
\end{abstract}

Kata-kata Kunci: Kebutuhan informasi; film; tunarungu; teks film; bahasa isyarat

\section{Information Seeking through Television and Films by Deaf People in Sumedang}

\begin{abstract}
Article $18 \mathrm{~F}$ of the 1945 Constitution states that everyone has the right to communicate and receive information. They can obtain information from various sources, including television and films. For deaf disabilities, information from television and movies is commonly inaccessible because of their limitations. This study revealed the motives of the "Movement for the Welfare of the Deaf" (Gerkatin) members in Sumedang Regency seeking information from television and movies and fulfilling the information needs. We conducted the research using a qualitative method with a case study approach. Data collection got through interviews, observations, and documents relevant to the research. We performed data analysis using the interactive data analysis method of Miles and Huberman. The result showed that information needs through television and films on deaf disabilities in 'Gerkatin' Sumedang are driven by internal and external motivation based on each individual's ten needs factors. Information in comedy and action films is easier to understand because the delivery is exciting and straightforward. They fulfilled the information needs of the movie by watching it in the cinema and on YouTube. Information on television and film is still tricky to access because of the lack of sign language interpreters and subtitles in every television show and movie in the cinema. They hope that there will be subtitles and a sign language interpreter in every Indonesian film screening for making it friendly for deaf disabilities.
\end{abstract}

Keywords: Information needs; film; hearing disabilities; subtitles; sign language

Korespondensi: Dr. Santi Susanti, S.Sos., M.I.Kom. Fakultas Ilmu Komunikasi, Universitas Padjadjaran. Jln. Raya Bandung-Sumedang Km 21, Jatinangor, Sumedang, 45363.Email: santi.susanti@unpad.ac.id 


\section{PENDAHULUAN}

Setiap manusia memiliki kebutuhan dalam hidupnya dan akan memikirkan cara bagaimana memenuhi kebutuhan tersebut. Rasa ingin memenuhi kebutuhan tersebut menumbuhkan motivasi untuk mencari informasi yang dapat menjawab keingintahuannya itu.

Setiap orang memiliki hak untuk mendapatkan informasi. Pasal 14 ayat (1) dan (2) Undang-undang tentang Hak Asasi Manusia mengegaskan bahwa "Setiap orang berhak untuk berkomunikasi dan memperoleh informasi yang diperlukan untuk mengembangkan pribadinya dan lingkungan sosialnya" dan "setiap orang berhak untuk mencari, memperoleh, memiliki, menyimpan, mengolah, dan menyampaikan informasi dengan menggunakan segala jenis sarana yang tersedia".

Hak untuk tahu merupakan hak konsitusional setiap warga negara Indonesia, karena dijamin pasal 18 F UUD 1945, yang menyatakan bahwa setiap orang berhak berkomunikasi dan memperoleh informasi (komnasham.go.id, 2016). Tetapi bagaimana dengan penyandang disabilitas yang sebenarnya sama-sama memiliki hak untuk berkomunikasi dan memeroleh informasi? apakah akses yang mereka dapatkan sama mudahnya dengan orang yang dapat mendengar dan dapat melihat?

Hasil observasi awal penelitian ini menunjukkan betapa tidak mudahnya menjalin komunikasi antara orang dengar dengan orang tuli, karena seringkali informasi yang disampaikan gagal dipahami. Apa yang dimaksudkan belum tentu sama dengan hasil interpretasi yang mereka terima.

Bahasa isyarat menjadi bahasa utama bagi disabilitas tuli. Bahasa isyarat sering dijumpai pada komunitas Tuli yang melibatkan penerjemah, teman, dan keluarga serta para penyandang Tuli itu sendiri. Bahasa isyarat yang digunakan di Indonesia adalah Bahasa Isyarat Indonesia(BISINDO) dan Sistem Isyarat Bahasa Indonesia (SIBI). Namun, individu yang menguasai bahasa isyarat masih sangat sedikit. Mayoritas orang orang yang menguasai bahasa isyarat hanyalah para penyandang Tuli itu sendiri. Oleh sebab itu, fungsi utama bahasa isyarat sebagai alat untuk berkomunikasi dan berinteraksi masih belum dapat terpenuhi (Olvia, Damajanti, \& Muljosumarto, 2018).

Kesulitan komunikasi dengan orang dengar terjadi karena penyandang tunarungu memiliki keterbatasan pendengaran sehingga tidak terbiasa dengan kata, kalimat bahkan rangkaian informasi dalam bentuk tulisan. Kosa kata yang mereka miliki terbatas. Hal ini diketahui dari penjelasan Ajeng, juru bahasa isyarat, yang menyebutkan bahwa ia pernah menyebutkan kata 'salut' kepada salah satu tuli. Ternyata mereka malah bertanya balik tentang kata yang 
dimaksud.

Kosa kata bahasanya aja masih banyak yang harus dibenerin. Ya.. kalo untuk anak anak denger pasti udah biasa lah ya. Nah, buat Tuli, bahkan 'salut' aja ngga ada dalam bahasa tulinya. Nah, kalau buat informasi, kadang kita aja yang denger suka masih percaya sama hoax. Apalagi mereka. Tapi, itu sebuah tantangan. Susah? Jelas. Tapi bukan berarti ngga mungkin. Kasian mereka tuh. Informasinya kurang (Ajeng, wawancara 9 Maret 2020)

Dalam upaya menjawab kebutuhan informasi tersebut, diperlukan upaya meminimalisir bahkan meniadakan kesenjangan informasi. Hal tersebut karena sebuah kesenjangan untuk mendapatkan informasi tersebut tidak dapat dihindari.

Peneliti memilih sebuah organisasi bernama Gerakan untuk Kesejahteraan Tunarungu Indonesia (Gerkatin) Kabupaten Sumedang, organisasi sosial tempat berkumpulnya penyandang tuli, yang berperan menjembatani dan menguatkan akses dalam memenuhi hak dari tunarungu di Sumedang. Jumlah anggota Gerkatin Sumedang sebanyak 120 orang yang seluruhnya tunarungu. Hanya empat puluh orang yang aktif, termasuk pengurus inti Gerkatin Sumedang.

Salah satu peran Gerkatin adalah memerjuangkan hak disabilitas tuli untuk mencapai kesetaraan dalam memeroleh hak yang sama dengan orang yang mendengar. Penelitian Jannati (2019) mendeskripsikan bentuk dukungan sosial yang diberikan oleh Gerakan untuk Kesejahteraan Tunarungu Indonesia (Gerkatin) kepada teman Tuli. Juga meneliti tentang pengaruh teman Tuli yang telah bergabung di organisasi ini. Hasil penelitiannya menunjukkan bahwa dukungan sosial Gerkatin meliputi: dukungan sosial, berupa dukungan informatif dengan adanya Juru Bahasa Isyarat JBI), dan sosial media yang membantu teman Tuli mengakses informasi; dukungan emosional, seperti teman sharing antarsesama anggota; dukungan instrumental, seperti tempat-tempat belajar Bahasa Isyarat Indonesia (BISINDO) sebagai akses sosialisasi kepada masyarakat; dukungan penghargaan, seperti JBI di televisi atau di acara-acara formal; dan dukungan kelompok, seperti berbagi rasa antarsesama teman Tuli. Teman Tuli menjadikan Gerkatin sebagai wadah kesejahteraan mereka, agar terhindar dari diskriminasi (Jannati, 2019).

Penelitian Ranti Rahayu Kinanti (2015) tentang Gerkatin Kota Solo, menunjukkan, Gerkatin melaksanakan kegiatan membantu tunarungu di Kota Surakarta untuk mencapai kesetaraan dalam mengembangkan bakat, hak yang sama, dan bersosialisasi dengan warga. Dengan melakukan kegiatan untuk mencapai kesetaraan penyandang disabilitas tuli, Gerkatin Solo ingin mendidik masyarakat tentang ketulian dan meluruskan penilaian mereka tentang penyandang disabilitas tuli. Selain itu, 
Pemerintah dapat memahami kebutuhan para penyandang disabilitas tuli di bidang informasi dan pendidikan, sehingga tidak ada lagi diskriminasi tentang bahasa isyarat, bahasa ibu penyandang cacat tuli. Bahasa ini harus dapat berkembang seperti bahasa Indonesia (Kinanti, 2015).

Dua penelitian terdahulu menggambarkan peran Gerkatin terhadap anggotanya untuk mencapai kesetaraan dalam berperilaku, serta mendapatkan hak dan akses yang sama dalam menjalani kehidupannya. Salah satunya mengenai kebutuhan informasi, yang diakses melalui media massa. Media massa dapat berperan dalam membantu tuna rungu untuk mengakses kebutuhan informasinya, antara lain melalui film dan televisi.

Perkembangan film dari film bisu ke film bersuara/"talkies" pada tahun 1927 merupakan sebuah perkembangan besar di dunia film. Namun, hal ini menjadi bencana bagi para penyandang tuli, karena cara penyampaian cerita film yang awalnya mengutamakan visual dan teks, menjadi penggunaan dialog para aktor dan suara tanpa menampilkan teks dari dialog tersebut untuk dibaca oleh para penyandang disabilitas (Satyadharma, Nalan, \& Dwimarwati, 2020).

Banyak sekali tipe suara dalam sebuah film yang tidak bisa dinikmati oleh penyandang disabilitas tuli, diantaranya: on-screen dialogue, off-screen dialogue, on-screen action sound, off-screen action sound, background noise, music soundtrack, in-story media, dan sound effect. Seperti yang dikatakan Wulan bahwa indera yang berperan utama agar tayangan televisi dapat dinikmati adalah penglihatan dan pendengaran (Permana, 2019), sehingga menjadi kendala bagi para tuli dalam menikmati atau mengapresiasi sebuah karya film yang memang merupakan sebuah pengalaman audiovisual (Satyadharma et al., 2020).

Penelitian ini mengarah kepada kajian kebutuhan tuli akan informasi melalui media massa, termasuk televisi dan film. Informasi apa yang sesuai, bagaimana mereka mengakses informasi yang mereka butuhkan, agar sesuai dengan yang mereka harapkan. Penelitian ini bertujuan untuk mengungkap motivasi yang mendorong anggota Gerkatin Kabupaten Sumedang memenuhi kebutuhan informasi melalui film dan televisi, serta mengungkapkan upaya pemenuhan kebutuhan informasi anggota Gerkatin Kabupaten Sumedang melalui film dan televisi.

Abraham Maslow mengembangkan Teori Hierarki Kebutuhan manusia yang meliputi lima kategori motif yang disusun dari kebutuhan yang paling rendah yang harus dipenuhi terlebih dahulu sebelum memenuhi kebutuhan yang lebih tinggi. Terdiri dari kebutuhan fisiologis, kebutuhan rasa aman, kebutuhan sosial 
(rasa cinta dan memiliki), kebutuhan akan penghargaan, dan kebutuhan aktualisasi diri.

Kebutuhan fisiologis merupakan kebutuhan yang berada di bagian bawah segitiga dan termasuk kebutuhan paling dasar. Termasuk di antaranya adalah kebutuhan-kebutuhan untuk memenuhi dorongan biologis dasar seperti makanan, udara, air dan tempat tinggal. Kebutuhan rasa aman menempati tingkat kebutuhan kedua. Kebutuhan keamanan diaktifkan setelah kebutuhan fisiologis terpenuhi. Kebutuhan sosial: (rasa cinta dan memiliki) mewakili kebutuhan tingkat ketiga. Mereka diaktifkan setelah kebutuhan rasa aman terpenuhi. Kebutuhan sosial mengacu pada kebutuhan untuk berafiliasi yaitu (kebutuhan untuk dicintai dan diterima oleh orang lain). Kebutuhan penghargaan, mewakili kebutuhan tingkat keempat, yang mencakup kebutuhan untuk menghargai diri sendiri dan persetujuan orang lain. Kebutuhan aktualisasi diri: Ini menempati tingkat terakhir di puncak segitiga. Ini mengacu pada kebutuhan seseorang untuk mengembangkan potensi sepenuhnya. (Kaur, 2013).

\section{METODE PENELITIAN}

Penelitian ini menggunakan metode kualitatifdenganpendekatan studikasus. Metode kualitatif digunakan untuk mengeksplorasi dan memahami masalah sosial atau kemanusiaan
(Creswell, 2007). Penelitian dilakukan untuk memahami fenomena yang dialami subyek penelitian. Sering juga disebut metode penelitian naturalistik, karena penelitiannya dilakukan pada kondisi alamiah, dengan peneliti sebagai instrumen kunci dan hasil penelitian kualitatif lebih menekankan makna dari pada generalisasi (Sugiyono, 2012).

Dalam kualitatif, peneliti tidak membuat suatu situasi atau eksperimen untuk melihat bagaimana upaya pemenuhan kebutuhan informasi disabilitas tunarungu. Prosesnya berjalan apa adanya seperti yang berlangsung di lapangan. Peneliti sebagai instrumen utama bertugas mengumpulkan data.

Melalui pendekatan studi kasus, peneliti mengeksplorasi kehidupan nyata, sistem terbatas kontemporer (kasus) atau beragam sistem terbatas (berbagai kasus), melalui pengumpulan data yang detail dan mendalam yang melibatkan berbagai sumber informasi atau sumber informasi majemuk (misalnya, pengamatan, wawancara, bahan audio visual, dokumen dan berbagai laporan), dan melaporkan kasus dan tema kasus (Creswell, 2007). Tujuan studi kasus adalah memberikan gambaran secara mendetail tentang latar belakang, sifat-sifat serta karakterkarakter yang khas dari kasus, maupun status dari individu, yang kemudian dijadikan suatu hal yang bersifat umum (Nazir, 2005). Dalam penelitian ini fenomena sedang berlangsung 
dan akan terus berkembang.

Metode kualitatif pendekatan studi kasus digunakan dalam penelitian ini untuk mengungkap kebutuhan informasi dan upaya pemenuhan kebutuhan informasi melalui film bagi disabilitas tunarungu di Gerkatin Kabupaten Sumedang. Pemilihan informan dilakukan melalui teknik purposive sampling, yaitu pengambilan sumber data dengan pertimbangan tertentu, agar informasi yang diperoleh sesuai dengan studi yang dilakukan. Pertimbangan tersebut misalnya orang tersebut dianggap memiliki pengetahuan tentang yang kita harapkan, atau sebagai penguasa yang akan memudahkan peneliti menjelajahi objek atau situasi sosial yang diteliti (Sugiyono, 2012).

Penelitian ini pun menggunakan teknik snowball sampling, suatu metode untuk mengidentifikasi, memilih dan mengambil sampel dalam suatu jaringan atau rantai hubungan berkesinambungan. Peneliti menyajikan suatu jaringan melalui gambar sociogram berupa gambar lingkaran-lingkaran yang dihubungkan dengan garis. Setiap lingkaran mewakili satu responden atau kasus, dan garis-garis menunjukkan hubungan antarresponden atau antar kasus (Neuman, 2014). Sederhananya, peneliti memilih informasi berdasarkan informasi dari informan sebelumnya yang diwawancarai.

Memilih objek pada penelitian kualitatif berdasarkan padaalasan-alasan yang disesuaikan dengan tujuan penelitian. Informan penelitian ini terdiri dari pengurus dan anggota Gerkatin Sumedang serta orang-orang terdekat informan disabilitas tunarungu, serta orang-orang yang terlibat dekat dan bekerjasama dalam waktu yang cukup lama yang dianggap memiliki kedekatan dengan informan berdasarkan pemaparan yang disampaikan informan.

Pemilihan informan berdasarkan kriteria sebagai berikut: Pengurus dan anggota Gerkatin Sumedang yang menjadikan televisi atau film sebagai salah satu akses pemenuhan kebutuhan informasi, pengurus dan anggota Gerkatin Sumedang yang bersedia diwawancarai untuk memberikan informasi sejelas-jelasnya, pengurus dan anggota Gerkatin Sumedang aktif dalam organisasi tersebut minimal satu tahun, supaya cukup mengetahui dinamika yang terjadi dalam organisasi tersebut, disebutkan oleh anggota Gerkatin sebagai keluarga, teman terdekat atau memiliki hubungan dekat dan mengetahui sedikit banyak seputar disabilitas tunarungu, serta pemenuhan informasi melalui film yang dilakukan oleh pengurus maupun anggota Gerkatin Sumedang.

Melalui tabel 1 penulis sajikan gambaran singkat tentang informan penelitian berdasarkan jabatan, keaktifan keanggotaan, umur, profesi, dan tingkat pendidikan. 
Tabel 1 Data profil informan

\begin{tabular}{|c|c|c|c|c|c|c|}
\hline No. & Nama & Jabatan & Keanggotaan & Umur & Profesi & Tingkat Pendidikan \\
\hline 1 & Rosmayadi & $\begin{array}{l}\text { Ketua Gerkatin } \\
\text { Sumedang }\end{array}$ & Aktif & 39 Tahun & Designer & SMA \\
\hline 2 & Krisna Nugraha & $\begin{array}{l}\text { Wakil Ketua dan } \\
\text { Sekretaris }\end{array}$ & Aktif & 22 Tahun & Deaf Activist & SMA \\
\hline 3 & Yani Sumaryani & $\begin{array}{l}\text { Darma Wanita, } \\
\text { Anggota Gerkatin }\end{array}$ & Aktif & 36 Tahun & $\begin{array}{l}\text { Ibu Rumah } \\
\text { Tangga }\end{array}$ & SMP \\
\hline 4 & Wulandari & Anggota Gerkatin & Aktif & 25 Tahun & $\begin{array}{l}\text { Ibu Rumah } \\
\text { Tangga }\end{array}$ & SMA \\
\hline 5 & Tamara M & Juru Bahasa Isyarat & Aktif & 22 Tahun & Mahasiswa & $\mathrm{S} 1$ \\
\hline 6 & Ajeng Sri Rahayu & $\begin{array}{l}\text { Juru Bahasa Isyarat, } \\
\text { Relawan Gerkatin }\end{array}$ & Aktif & 29 Tahun & Wirausaha & $\mathrm{S} 1$ \\
\hline 7 & Hani Asyifa & Relawan Gerkatin & Aktif & 20 Tahun & Pelajar & SMA \\
\hline
\end{tabular}

Sumber: Data Penelitian, 2020

\section{HASIL DAN PEMBAHASAN}

Motif Pencarian Informasi. Pencarian informasi dipengaruhi oleh motivasi, dan pencarian informasi dipilih dan dipilah berdasarkan kebutuhan. Informasi menjadi kebutuhan penting untuk mendukung pekerjaan atau kegiatan atau seluruh aktivitas yang manusia lakukan dalam hidup. Motivasi informan untuk memenuhi kebutuhan informasinya dilakukan melalui beragam cara. Pengalaman setiap informan dalam berinteksi dengan orang-orang di sekitarnya serta penerimaan akan kondisi fisiknya memengaruhi motivasi setiap individu untuk memenuhi kebutuhan informasinya.

Rosmayadi (39 tahun), misalnya, membutuhkan informasi mengenai berita, jalanjalan, lokasi suatu tempat, untuk mengetahui lokasi, informasi kelas bahasa isyarat, desain, foto-foto kegiatan (Rosmayadi, wawancara 11
Maret 2020).

Tidak jauh berbeda dengan Rosmayadi, Krisna pun membutuhkan informasi untuk menunjang kegiatan sehari-hari yang dilakukannya, seperti berita, informasi kelas isyarat, film bagus, design bagus, atau tutorial sama pekerjaan.

Sementara itu, Yani Sumaryani (36 tahun), anggota Gerkatin yang telah berumah tangga, mengarahkan pencarian informasinya pada seputar aktivitas ibu rumah tangga, misalnya informasi tentang resep atau hiburan untuk menghindari rasa bosan ketika sedang mengerjaan pekerjaan rumah tangga.

Suka nonton film yang ada di tv, seru sekali. Saya nontonnya sambil mencuci, sambil menyetrika. Terus juga kalau ada anak SMAnya cerita saya suka. Nonton film di bioskop juga saya suka sekali, sering sama suami, bagus, saya suka Dilan (Yani, wawancara 11 Maret 2020).

Begitu pula dengan Wulandari yang 
aktifitas hariannya tidak jauh berbeda dengan

Ibu Yani sebagai ibu rumah tangga.

"Suka! Banyak, resep makanan, terus hiburan kalau nonton sinetron, kalau Youtube suka liat yang jahit-jahit atau keterampilan rumah tangga, supaya otaknya tidak rusak." (Wulandari, wawancara 11 Maret 2020).

Waktu yang dibutuhkan anggota Gerkatin untuk pencarian informasi tidak tentu. Anggota organisasi cenderung menggunakan gawai atau pencarian informasi secara online, sebab hal tersebut memudahkan mereka dalam mencari informasi yang sesuai dengan kebutuhan mereka. Kebutuhan informasi anggota Gerkatin memiliki ciri tersendiri, yakni informasi yang disertai gambar. Dalam hal kebutuhan informasi, anggota Gerkatin memerlukan pendamping atau penerjemah untuk menerjemahkan informasi yang diperoleh.

Terkait pencarian informasi melalui tayangan audio visual, baik Rosmayadi, Yani, Wulandari, maupun Krisna memiliki pendapat yang berbeda tentang hasrat menonton film Indonesia. Rosmayadi menjadikan menonton tayangan audio visual sebagai hiburan,

"Untuk hiburan kalau sedang bosan. Suka nonton yang lucu-lucu, tembak-tembak, liat film drama juga, terharu, tapi tidak suka film dewasa" (Rosmayadi, wawancara 11 Maret 2020).

Film merupakan media yang dapat menyampaikan informasi mengenai identifikasi perasaan sedih, terharu, senang dan lainlain. Yani, yang senang menonton film, sangat menyukai film Indonesia, karena menurutnya lucu dan membuat dia senang. Yani mengungkapkan bahwa

Saya sangat suka dengan film Indonesia. Saya selalu tunggu-tunggu. Saya berharap seluruh film Indonesia ada teksnya. Kalau tidak ada teksnya, saya suka memaksakan diri untuk lebih teliti membaca gerak bibirnya, atau mengikuti teman dengar yang dalam satu gedung bioskop. Kalau mereka tertawa saya ikut. Hehehe.. (Yani, wawancara 11 Maret 2020).

Yani merupakan salah satu anggota yang sangat aktif mengajak teman-temannya di Gerkatin untuk menonton film. Yani mengungkapkan, ada perasaan sedih dan senang ketika menonton film Indonesia.

Lumayan, suka sedih sendiri dan hiburan kalau lagi bete. Suka nonton sambil nyetrika, makan, botram, makin seneng kalau suami juga ikut. Jadi seruu! (Yani, wawancara 11 Maret 2020).

Wulandari pun sangat menyukai film. Ia selalu menonton film di bioskop. Wulandari merupakan ibu rumah tangga yang memiliki anak yang dapat mendengar.

Meski para teman tuli dapat mengakses film dan tayangan televisi, akan tetapi, mereka masih kesulitan memahami isi informasi yang ada di dalamnya. Hal ini disebabkan, karya kreatif dari para content creator maupun para sineas belum ramah pada teman Tuli. Krisna mengungkapkan, informasi yang disampaikan 
film Indonesia belum diperuntukkan untuk

Teman Tuli, karena orang yang membuat film Indonesia belum mengerti informasi apa yang dibutuhkan oleh disabilitas tunarungu, juga masih jarangnya teks dalam film Indonesia.

"Film Indonesia penting, cuman jarang subtitle. Jadi ngga ngerti, ngga paham, bingung, jadi film cuman menghibur. Belum banyak informasi yang bisa diambil kalau buat teman tuli. Kalau informasi sedikit, gimana saya mau dapet informasi kalau saya ngga ngerti filmnya." (Krisna, wawancara 11 Maret 2020).

Krisna lebih memilih menonton film yang diproduksi oleh luar negeri. Menurutnya, film Indonesia kurang efektif dalam memberi informasi, karena tidak dibubuhi teks film, sehingga menganggap film Indonesia belum ramah disabilitas tunarungu. Tetapi, ia mengaku tetap mendukung film Indonesia jika film tersebut sudah dibubuhi teks film, agar disabilitas tunarungu paham pesan yang disampaikan dalam film tersebut.

Meski lebih sering menonton film di bioskop, Wulandari sepakat dengan Rosmayadi, Krisna Nugraha dan Ibu Yani Sumaryani mengenai kekurangan film Indonesia, yakni tidak adanya teks film.

Sulit kalau gak ada teks, suka ngga ngerti, padahal ingin sekali nonton film Indonesia di bioskop, tapi jarang yang ada teks nya. Kalau ada, biasanya suka nonton ramerame. Tapi, kalau sampai ruangan tidak ada teksnya, saya jadinya nonton orang dengar. Mereka sedih, baru saya ikut sedih, mereka senang, saya ikut senang. Ada teks film juga dari China, Inggris Arab, saya nggak bisa bacanya. Jadi harus Bahasa Indonesia (Wulandari, wawancara 11 Maret 2020).

Motivasi tumbuh karena ada faktor pendorong dari dalam maupun luar diri seseorang dalam memenuhi kebutuhannya hidupnya. Dita Mediasari, psikolog, menjelaskan, sumber motivasi yang mendorong setiap orang dalam memenuhi kebutuhan hidupnya, berbeda, tergantung pengalaman internal dan eksternal yang mereka alami.

Kekuatan ini berasal dari dalam diri atau lingkungan luar. Apa aja faktornya? Bisa mulai dari karena senang melakukannya. Bisa karena tujuannya jelas, ada yang mau dicapai, bisa karena memuaskan rasa penasaran, terus juga kebutuhan. Nah, ini yang mendasar dan biasanya paling bertahan karena motivasi ini sifatnya berubah ubah dan fluktuatif. (Dita, wawancara 2020).

Pencarian informasi ini didasari oleh adanya motivasi atau motif. "Semakin kuat motivasi, kita kaya di fill in energy di tubuh, nanti outputnya bisa semangat, bisa jadinya energi positif, bisa tenaga fisik" (Dita, wawancara 20 April 2020).

Motivasi untuk memenuhi kebutuhan informasi melalui film Indonesia dipengaruhi oleh pengalaman pribadi yang membuat individu menggunakan energinya untuk mendekat kepada informasi atau menghindar dari informasi yang terdapat dalam film Indonesia. Setiap individu memiliki motivasi yang berbeda sesuai dominasi internal atau pengaruh luar, yang juga berkenaan dengan penerimaan keterbatasan informan. Faktor-faktor penyebab munculnya motivasi 
dijelaskan oleh Dita sebagai berikut,

Kalau didasarkan pada kebutuhan, biasanya akan banyak faktor lain yang memengaruhi seseorang untuk mencari informasi. Setiap orang akan berbeda, tergantung pada kebutuhannya apa? Kesenangannya apa? Bisa jadi terinsiprasi dari siapa? Kontrol pribadinya seperti apa? Gitu.. Nah, selain dalam diri, motivasi juga datengnya bisa dari lingkungan sekitar contohnya tuntutan pekerjaan, kebutuhan uang, budaya yang mengharuskan, atau ada standarisasi dari masyarakat, ya macem macem. (Dita, wawancara 20 April 2020).

Berdasarkan penjelasan tersebut, sumber motivasi terbagidua, yakni internal dan eksternal, yang mendasari seseorang mendekatkan diri kepada informasi atau menghindari informasi. Sumber motivasi terdiri dari motivasi intrinsik, arus tantangan, eksternal, ekstrinsik, posibilitas diri atau terinspirasi, dan aspek positif.

Motivasi intrinsik, bisa berupa kesenangan yang sifatnya spontan, seperti yang terjadi pada informan Yani Sumaryani dan Wulandari. Selain dari pengalaman eksternalnya, kesenangannya menonton film Indonesia membuat keduanya secara spontan mencari film dengan genre yang mereka sukai. Arus tantangan, terjadi pada Krisna dan Wulandari, yang beranggapan, membuktikan sesuatu kepada orang sekitar merupakan aktualisasi diri yang menantang dan merupakan motivasi terbesar dalam memenuhi kebutuhan informasi.

Faktor eksternal, berupa dukungan dari keluarga, juga kebutuhan untuk dapat bekerja pada bidangnya hingga mendapatkan uang, merupakan sumber motivasi yang juga dirasakan oleh anggota Gerkatin, khususnya Rosmayadi dan Krisna Nugraha. Faktor ekstrinsik, memiliki tujuan. Biasanya timbul dari keharusan dalam pekerjaan yang mereka geluti, seperti Rosmayadi, yang harus memelajari dan mencari informasi dari berbagai platform termasuk film Indonesia, agar dapat membaca pasar dan perkembangan selera masyarakat, untuk mendukung pekerjaannya sebagai desainer.

Posibilitas diri atau terinspirasi, setelah mengetahui bagaimana orang-orang dengar melakukan sesuatu, penyandang disabilitas tidak jarang terinspirasi dengan cara orang dengar bekerja, apa yang mereka suka dan lainlain. Aspek positif, berada dalam suasana hati. Sumber motivasi ini yang biasanya jarang orang sadari, karena kesenangan terhadap sesuatu, ternyata dapat mendukung kita melakukan sesuatu. Seperti yang dilakukan oleh Ibu Yani yang tidak peduli dengan ada atau tidaknya teks dalam film Indonesia, atau apakah film yang ditonton akan bermanfaat atau tidak. Ia akan serta merta menuju bioskop untuk menonton film, demi memenuhi kebutuhannya akan rasa senang dan bahagia saat menonton film.

Sumber motivasi berperan penting dalam menggiring individu melakukan perilaku tertentu, karena motivasi memengaruhi 
tingkah laku, pikiran, perasaan, bahkan harapan. Motivasi memiliki tiga elemen yang menggerakkan manusia untuk melakukan aksi, yakni kebutuhan (needs), motivasi (dorongan/ drives), dan tujuan (goals) (Wardalisa, 2013).

Kebutuhan (needs) yang belum terpenuhi akan membentuk motivasi yang menggerakkan seseorang melakukan aksi. Motivasi (dorongan/ drives) bersumber dari dalam diri individu (internal) maupun pengalaman atau peristiwa yang terjadi di luar (eksternal). Pada penelitian ini, sumber motivasi setiap informan beragam. Ada yang bersumber dari lingkungan sekitar atau keluarga, ada juga yang berdasarkan pengaruh dalam diri yang sangat mendominasi, faktor ingin berkarya, ingin bermanfaat bagi banyak orang, dan ingin membuktikan bahwa dengan keterbatasannya, ia mampu seperti orang normal.

Semua motivasi tersebut pada dasarnya menjadi kunci yang akan menggerakkan individu untuk bertingkah laku, bisa berupa belajar secara autodidak mengenai BISINDO hingga belajar lewat sebuah alur cerita film Indonesia. Dalam penelitian ini, motivasi internal dan eksternal mendorong informan untuk melakukan pencarian informasi yang dibutuhkan melalui media film Indonesia. Tujuan yang ingin dicapai masing-masing individu bisa berbeda tergantung darimana sumber motivasi tersebut berasal.
Tujuan (goals) merupakan pencapaian yang ingin diraih berdasarkan kebutuhan yang mendasarinya. Tujuan yang dicapai bisa menjadi suatu parameter yang dapat diukur dan tidak dapat diukur. Dalam penelitian ini tujuan setiap individu berbeda berdasarkan sumber dan kebutuhan yang mendasarinya. Ibu Yani dan Wulandari merasa penting mencari informasi mengenai romantisme sekolah melalui film Indonesia, karena tujuan yang ingin dicapai yaitu mengobservasi kesenangan diri dan suami. Sedangkan tujuan yang ingin dicapai Krisna dan Rosmayadi adalah mendapatkan pekerjaan, karena sumber motivasinya didapatkan dari pihak luar dan ingin membuktikan bahwa informan merupakan orang yang dapat bermanfaat, juga sebagai ajang aktualisasi diri.

Motivasi berfungsi untuk mendorong munculnya perilaku atau perbuatan, pengaruh untuk mencapai tujuan dan penggerak menuju kebutuhannya. Berdasarkan pemaparan triangulator, pencarian informasi dipengaruhi oleh motivasi, serta dipilih dan dipilah berdasarkan kebutuhan.

"Pencarian informasi ini dipengaruhi oleh bermacam-macam sebab atau didasari oleh adanya motivasi. Nah, pencarian informasi yang dipengenin sama individu dipengaruhi juga sama kebutuhan akan informasi yang dipengenin. Semakin kuat motivasi, kita kaya di fill in energy ngalir tuh di tubuh, nanti outputnya bisa semangat, bisa jadinya energi positif, bisa tenaga fisik." (Dita, wawancara 20 April 2020). 


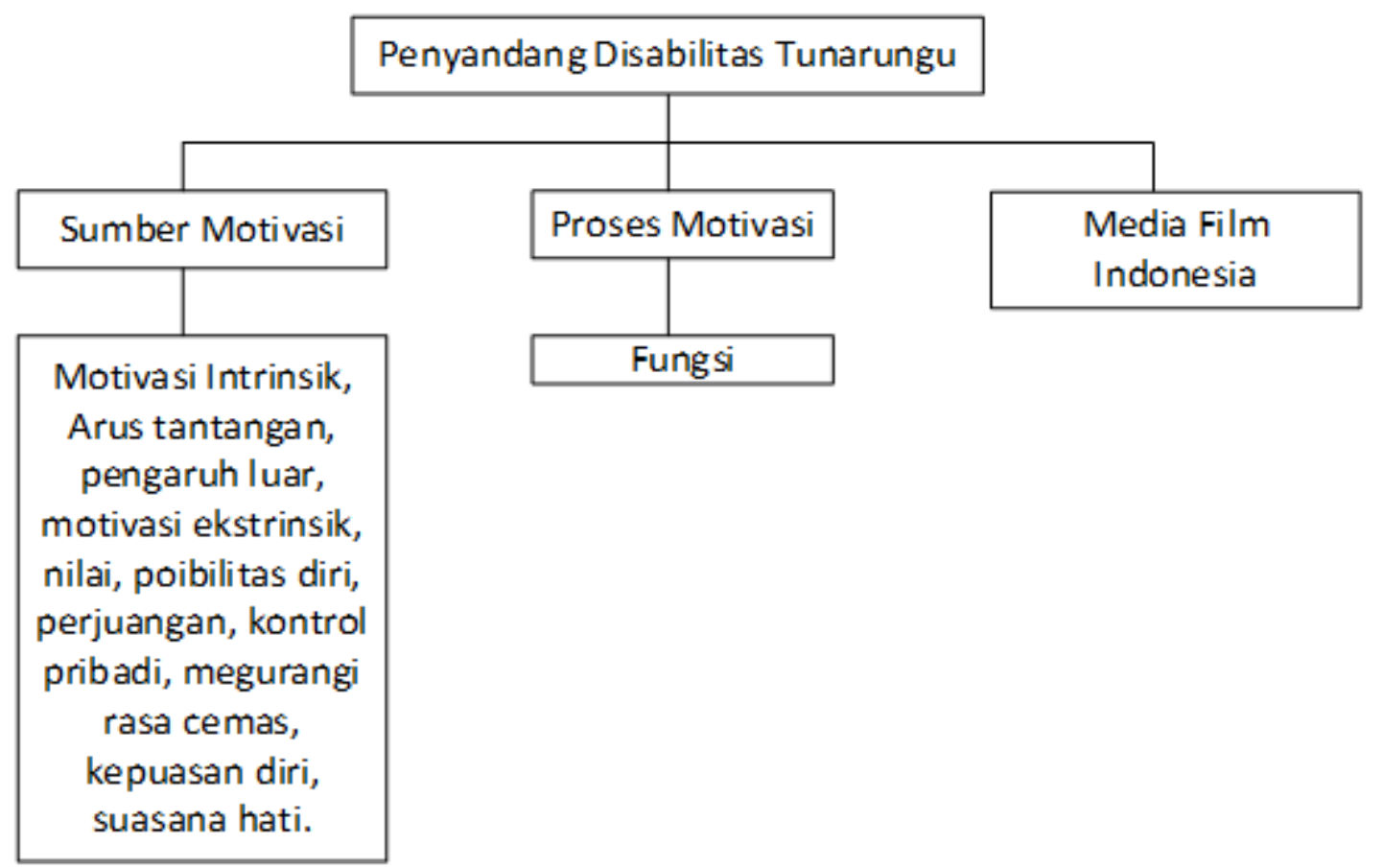

Sumber: Olahan Data Penelitian, 2020

\section{Gambar 1 Model motivasi untuk memenuhi kebutuhan informasi melalui film Indonesia}

Motivasi menjadikan sebuah kekuatan dan daya, yang dapat mewujudkan kesiapan perorangan maupun golongan, untuk beroperasi dan berupaya menuju tujuan tertentu. Motivasi merupakan kunci kedua setelah kebutuhan yang saling berpengaruh dalam pencarian informasi.

Setiap orang membutuhkan informasi dalam hidupnya. Menerima, memberi dan memanfaatkan informasi dilatarbelakangi oleh kebutuhan informasi orang yang membutuhkan (Safii, 2019). Anggota Gerkatin dan pengurusnya membutuhkan informasi terkait hidup dan kehidupannya. utama mereka.

Bagi disabilitas tunarungu, informasi dibutuhkan untuk pemecahan masalah. Namun, dalam mencari solusi pemecahan masalah, ada ketergantungan untuk melibatkan anggota dan relawan sebagai benang merah yang membantu mereka mendapatkan solusi terbaik.

Abraham Maslow beranggapan bahwa semua motivasi merupakan reaksi atas persepsi individu pada lima macam tipe dasar kebutuhan. Maslow menyusun teori motivasi manusia, dimana variasi kebutuhan manusia dipandang tersusun dalam bentuk hierarki. Lima macam kebutuhan tersebut yaitu kebutuhan fisiologis, kebutuhan akan rasa aman, kebutuhan untuk diterima, kebutuhan untuk dihargai dan kebutuhan aktualisasi diri. Dalam teori isi (content theories), Maslow menegaskan bahwa kebutuhanlah yang memotivasi seseorang. Sejatinya setiap manusia selalu mempunyai kebutuhan yang diupayakan untuk dipenuhi (Iskandar, 2016). 
Inti dari Teori Hierarki Kebutuhan Abraham Maslow yaitu manusia merupakan makhluk yang berkeinginan, selalu ingin lebih banyak dan akan terus ada hingga akhir hayat tiba. Kebutuhan ini sifatnya berjenjang. Kebutuhan yang lebih rendah seperti makan dan minum adalah yang terkuat, karena pemenuhannya harus didahulukan (Feist, 2010)

Kebutuhan informasi akan muncul apabila terdapat faktor yang mendorong seseorang untuk melakukan pencarian informasi. Setiap individu memiliki kebutuhan informasi yang berbeda-beda. Hal tersebut berdampak pada cara pemenuhan yang berbeda-beda pula antara satu individu dengan individu lainnya (Laloo, 2002). Perbedaan tersebut berdasarkan 10 faktor dalam kebutuhan informasi (Nicholas, 2000), yakni, faktor pekerjaan, kebudayaan, kepribadian, sadar akan informasi, jenis kelamin, usia, ketersediaan waktu, akses, faktor biaya, dan faktor informasi berlebih.

Dalam dunia kerja, seorang pekerja membutuhkan informasi terkait pekerjaan yang digeluti. Pekerjaan tidak hanya dalam lingkup seseorang yang bekerja di kantor, namun, bisa juga seseorang yang memiliki profesi tertentu, seperti salah seorang anggota Gerkatin Sumedang, Rosmayadi yang berprofesi sebagai desainer.

Rosmayadi menonton film untuk belajar mengenai mix and match suatu konten audiovisual. Hasil karyanya bisa dinikmati di Youtube Gerkatin Sumedang. Rosmayadi berharap, suatu saat ia dapat membuat film yang bisa dinikmati oleh orang yang bisa mendengar dan tunarungu.

Tugas ibu rumah tangga juga merupakan pekerjaan yang membutuhkan informasi, terlebih dari media audiovisual. Yani dan Wulandari menonton film atau televisi untuk meningkatkan rasa bahagia dan senang ketika sedang menjalankan pekerjaannya sebagai ibu rumah tangga, atau mencari informasi dari media audiovisual.

Menurut informan sekunder, pencarian informasi dalam film merupakan suatu hal yang penting karena informasi bisa berupa apa saja, dan didapatkan dari mana saja. Menurut Tamara, berdasarkan pengalamannya tiga tahun belajar mengenai disabilitas tunarungu, ia menyimpulkan bahwa teman tuli itu sangat membutuhkan aksesibilitas yang memudahkan mereka dalam beraktifitas, seperti tulisan yang besar saat di stasiun kereta api, bis, penunjuk arah, atau butuh juru bahasa isyarat dalam tayangan $\mathrm{tv}$, atapun teks dalam film (Tamara, wawancara 9 April 2020).

Ajeng Sri Rahayu, Juru Bicara Isyarat, yang sangat dekat dengan anggota Gerkatin, menuturkan, disabilitas tunarungu membutuhkan informasi yang sama dengan orang dengar, tentang hidup dan berkehidupan, 
tentang hidupnya sehari-hari, bahkan tips kehidupan sehari-hari.

"Masih banyak kosa kata yang belum mereka tau. Tata bahasanya juga harus dibenerin. Kalau buat informasi, semua harus tau, berita, sosial life. Nah, kadang kita aja yang denger suka masih percaya sama hoax. Apalagi mereka, tapi ya itu sebuah tantangan, susah? Jelas. Tapi bukan berarti ngga mungkin, nah kasian ya mereka tuh. Informasinya kurang," (Ajeng, wawancara 13 April 2020).

Informasi selalu berisi kebenaran dari sebuah kenyataan atau fakta yang ada, apabila informasi yang berisi hoax dipercaya oleh masyarakat, maka dampaknya adalah sama dengan jika informasi tersebut benar (Suwarno, 2010). Kesadaran akan informasi melalui sebuah media film Indonesia dinyatakan langsung oleh keempat informan utama.

"Untuk hiburan kalau sedang bosan, luculucu, suka nonton, suka nonton yang prank juga, jail-jail, tembak-tembak. Film drama liat juga, terharu tapi tidak suka film dewasa" (Rosmayadi, wawancara 11 Maret 2020).

"Film banyak kasih saya hiburan, kalau informasi sedikit karena gimana saya mau dapet informasi kalau saya ngga ngerti filmnya." (Krisna, wawancara 11 Maret 2020).

"Lumayan suka sedih sendiri dan hiburan kalau lagi bete. Suka juga nonton sambil makan, botram, makin seneng kalau ada suami juga ikut, jadi seruu! Saya menikmati, soalnya seru sekali" (Yani, wawancara 11 Maret 2020).

"Suka nonton film kalau ada film bagus, ada informasinya di grup atau media sosial, anak saya juga bisa denger jadi suka nemenin anak ke bioskop. Kalau di rumah suka download film nonton sambil makan bareng keluarga, anak, suami sama ibu" (Wulandari, wawancara 11 Maret 2020).

Dari pernyataan tersebut, keempat informan sudah memilki kesadaran dalam mencari informasi melalui film Indonesia, dan memanfaatkannya sebagai transfer perasaan, meskipun di sisi lain terdapat banyak keterbatasan dari film Indonesia sendiri. Berdasarkan jenis kelamin, dalam pencarian informasi wanita lebih jujur daripada pria. Wanita tidak segan bertanya kepada seseorang, sedangkan pria lebih memilih untuk segan bertanya dan mencari informasi tersebut dengan caranya sendiri (Nicholas, 2000).

Dalam hal ini anggota Gerkatin Sumedang berjenis kelamin perempuan cenderung lebih ekspresif dalam mencari dan mengemukakan pendapatnya dan cenderung malu saat ingin bertanya kepada teman yang lain untuk mengetahui informasi yang belum diketahui. Sedangkan anggota Gerkatin laki-laki mencari informasi yang dibutuhkan dengan melakukan pencarian melalui internet, youtube, dan media sosial.

Akses informasi diperoleh anggota Gerkatin Sumedang dengan menggunakan alat elektronik seperti smartphone, laptop, komputer, serta bantuan manusia. Anggota 
komunitas dapat berkomunikasi dengan teman tentang informasi tertentu. Anggota Gerkatin Sumedang membutuhkan instrumen atau akses lain yang membantu mereka mengakses film Indonesia, yaitu penambahan teks atau Juru Bicara Isyarat (JBI).

Bantuan akses informasi tersebut tidak hanya diterapkan dalam film Indonesia, juga dalam media sosial. Tamara berharap content creator video di Instagram, Youtube, film atau TV seharusnya mendukung kebutuhan informasi mereka, karena tidak bisa dipungkiri, kesenjangan itu ada.

"Butuh kejelasan sejelas jelasnya gitu, karena ngga cukup dengan literasi bacaan aja sebetulnya, realitanya kan mereka juga kurang mampu untuk memahami teks yang panjang dan rumit, karena pemahaman SPOK mereka pun belum sempurna gitu. Nah, adanya media harusnya bisa menjawab permasalahan tersebut sebagai sarana yang istilahnya mudah untuk digapai." (Tamara, wawancara 9 April 2020).

"Kendalanya di mereka, lagi-lagi masalah teks. Tolong sampaikan kepada sutradara atau insan perfilman untuk menambahkan teks dalam mahakarya mereka. Kasian juga temen-temen Tuli yang tidak bisa menikmati hasil karya anak bangsa sendiri, nah itu" (Ajeng, wawancara 13 April 2020)

"Film pun juga efektif, karena mereka seneng nonton dan ngobrolin soal film, tapi kalau film Indonesia jarang yang ada subtitlenya. Jadi tetep harus ada translatenya, karena film kan harusnya bisa dinikmati oleh siapapun." (Hani, wawancara 13 April 2020).

Dari pemaparan tersebut, diketahui bahwa tidak hanya informan utama yang menganggap akses informasi terkait film sangat terbatas. Tetapi, orang terdekat hingga Juru Bahasa Isyarat pun beranggapan demikian, karena ternyata film Indonesia belum menyentuh standar ramah disabilitas tunarungu.

Menurut Dita, media apapun efektif, termasuk media audiovisual. Dalam tahap perkembangannya, media memegang peranan penting untuk meminimalisir hambatan dari perkembangan kognitif, emosi, sosial dan perilaku.

"Gambar adalah memori yang sangat mudah diingat sebetulnya, dan saya menyimpulkan kalau film merupakan salah satu media yang efektif, dengan catatan perlu penambahan teks, karena mereka akan lebih frustasi dan bingung kalau dalam film itu banyak yang ngomong tapi ngga ada teks nya." (Dita, wawancara 20 April 2020).

Film Indonesia menjadi media efektif dalam menyampaikan informasi kepada disabilitas tunarungu, dengan jenis film komedi dan aksi, yang membungkus informasi sedemikian ringan hingga mampu dimengerti dengan mudah oleh disabilitas tunarungu. Dalam Teori Hierarki Kebutuhan, sangat dibutuhkan akses yang mudah untuk menjawab kebutuhan individu penyandang disabilitas, dan jenis film Indonesia komedi dan aksi ini berkaitan dengan aktualisasi diri, rasa aman dan lain-lain seperti yang telah diungkapkan oleh informan.

Ada dua hal yang dapat dilakukan untuk 
memenuhi kebutuhan informasi disabilitas tunarungu melalui film Indonesia, yakni penambahan teks film berbahasa Indonesia atau adanya juru bahasa isyarat. Dalam upaya mendapatkan kebutuhan tersebut, disabilitas tuli mengomunikasikannya kepada advokasi bioskop di Sumedang. Namun, belum berbuah hasil.

Menurut Dita Mediasari, empati adalah modal utama sebelum mengupayakan sesuatu, menjadikan ini sebagai prioritas yang perlu untuk dipikirkan bersama selaku masyarakat Indonesia, menganggap tidak ada perbedaan antara yang dapat mendengar dengan teman tuli agar informasi atau pesan yang ingin disampaikan dari film Indonesia dapat diterima dan dinikmati oleh disabilitas tunarungu.

"Kalau dari tinjauan media film apalagi Indonesia, harusnya ngga ada ya alesan untuk tidak menambahkan teks ataupun JBI untuk dinikmati oleh disabilitas tunarungu, karena mereka kan sifat menirunya sangat dominan lewat visual, diharapkan bisa ditingkatkan lagi aksesibilitas menonton untuk tunarungu, karena ya zaman sekarang siapa sih yang ngga suka nonton ya?" (Dita, wawancara 20 April 2020).

\section{SIMPULAN}

Pemenuhan kebutuhan informasi oleh disabilitas tunarungu di Gerkatin Sumedang didasari motivasi yang menggerakannya, yang terdiri dari motivasi ekstrinsik dan motivasi intrinsik. Motivasi tersebut berkaitan dengan kebutuhan dan harapan dari setiap informan.
Televisi dan film menjadi pilihan dalam memenuhi kebutuhan informasi disabilitas tunarungu Gerkatin Sumedang. Meski dalam kenyataan, akses untuk mendapatkan informasi tersebut terbatas, karena tidak semua tayangan televisi dan film diberi subtitle atau Juru Bahasa Isyarat yang memudahkan teman Tuli untuk memahami informasi dalam tayangan.

Oleh karena itu, upaya pemenuhan aksesibilitas perlu dilakukan melalui berbagai pihak yang memiliki empati pada kebutuhan disabilitas tunarungu akan informasi, baik secara langsung maupun tidak langsung, sebagai langkah kongkrit perwujudan Pasal 18 F UUD 1945 dan menjadikan film Indonesia sebagai film ramah disabilitas tunarungu.

\section{DAFTAR PUSTAKA}

Creswell, J. W. (2007). Qualitative Inquiry \& Research Design. California: SAGE Publications Inc.

Feist, J. (2010). Teori Kepribadian: Theories of Personality. Jakarta: Salemba Humanika. Iskandar. (2016). Implementasi Teori Hirarki Kebutuhan Abraham Maslow terhadap Peningkatan Kinerja Pustakawan. Khizanah Al-Hikmah: Jurnal Ilmu Perpustakaan, Informasi, Dan Kearsipan, 4(1), 23-34. https://doi.org/10.24252/kah.v4ila2

Jannati, M. S. (2019). Dukungan Sosial Gerakan untuk Kesejahteraan Tunarungu Indonesia (Gerkatin) terhadap Penyandang Tuli. Empati, 8(1), 60-68. https://doi. org/10.15408/empati.v8i1.14688

Kaur, A. (2013). Maslow's Need Hierarchy 
Theory : Aplications and Criticisms. Global Journal of Management and Business Studies, 3(10), 1061-1064. Retrieved from http://www.ripublication.com/gjmbs_spl/ gjmbsv3n10_03.pdf

Kinanti, R. R. (2015). Peranan Gerkatin untuk Kesetaraan Hak Penyandang Disabilitas di Kota Solo. FISIP Universitas Sebelas Maret, Solo.

komnasham.go.id. (2016). Hak untuk Tahu adalah HakAsasi Manusia. Retrieved March 28, 2020, from https://www.komnasham. go.id/index.php/news/2016/9/29/167/hakuntuk-tahu-adalah-hak-asasi-manusia.html Laloo, B. T. (2002). Information Needs, Information Seeking Behavior and Users. New Delhi: Ess Ess Publication.

Nazir, M. (2005). Metode Penelitian. Jakarta: Ghalia Indonesia.

Neuman, W. L. (2014). Social Research Methods; Qualitative and Quantitative Approaches (Seventh Ed). Essex: Pearson Education Limited.

Nicholas, D. (2000). Assessing Information Needs: Tools, Techniques and Concepts for the Internet Age. (2nd ed.). London: Aslib.

Olvia, V., Damajanti, M. N., \& Muljosumarto, C. (2018). Perancangan Media Informasi Tentang Bahasa Isyarat Indonesia. Jurnal DKV Adiwarna, 1(12), 1-9. Retrieved from http://publication.petra.ac.id/index.php/ dkv/article/view/7200/6528

Permana, R. S. M. (2019). Budaya menonton televisi di Indonesia: dari terrestrial hingga digital. ProTVF (3)1 53-67. https://doi. org/10.24198/ptvf.v3i1.21220

Putri, N. E., Hakim, N., \& Yamin, M. (2016). Ecologicall Footprint and Biocapacity Analysis for Flooding Prevention in South Sumatera. Jurnal Mimbar, 32(1), 58-64.

Safii, M. (2019). Redefining The Five Laws of Library Science in the Digital Age. 2nd International Conference on Culture and Language in Souteast Asia (ICCLAS 2018), 24-27. Atlantis Press. https://doi. org/10.2991/icclas-18.2019.7

Satyadharma, I. G. N. W., Nalan, A. S., \& Dwimarwati, R. (2020). Bentuk Film Dokumenter Ekspositoris Menggunakan Open Caption untuk Audiens dengan Keterbatasan Pendengaran. Pantun, Jurnal Ilmiah Seni Budaya, 5(2). Retrieved from https://jurnal.isbi.ac.id/index.php/pantun/ article/view/1426/940

Sugiyono. (2012). Metode penelitian kuantitatif, kualitatif dan $r \& d$. Bandung: Alfabeta.

Suwarno, W. (2010). Ilmu perpustakaan dan kode etik pustakawan. Yogyakarta: Ar Ruzz Media.

Wardalisa. (2013). Teori hirarki kebutuhan. Theory OfAbraham Maslow, 1-5. Retrieved from http://wardalisa.staff.gunadarma.ac.id 